\title{
MRダンパを設置した小型 3 層免震フレームのセミアクティブ振動制御実験 SEMI-ACTIVE SEISMIC RESPONSE CONTROL OF A THREE-STORY BASE-ISOLATED FRAME WITH MAGNETO-RHEOLOGICAL DAMPER
}

\author{
沈 里 通*, 荻野和 臣**, 曾田五月也*** \\ Li-tung SHEN, Kazuomi OGINO and Satsuya SODA
}

\begin{abstract}
The purpose of this study is to find out a proper algorithm for semi-active seismic response control of base-isolated building. In the study, in order to perform hundreds of shaking table test, a scaled base-isolated three-story steel frame with a miniature capacity adjustable damper is used. In the first part, mechanical properties of the miniature bypass type magneto-rheological fluid damper are studied based on a series of the sinusoidal displacement tests results. The Bingham model was found to be quite effective to simulate the mechanical properties of the MR damper. In the second part, several passive/semi-active control algorithms are studied, among which, both the response feed-forward control algorithm and the fuzzy control algorithm are found to be better than the other semi-active ones and the passive ones. It is also confirmed that test results compare with prior analytical ones fairly well.
\end{abstract}

Keywords: Magneto-rheological Damper, Bingham Model, Semi-active Control, Response Feed-forward Control, Fuzzy Control, Skyhook Control MR ダンパ，ビンガムモデル，セミアクティブ制御，态答予測制御，ファジィ制御，スカイフック制御

1. はじめに

建築物の耐震性能を向上することを目的として各種の制振構造や 免震構造が適用されるようになっている。これらの構造では、エネ ルギー吸収装置（ダンパ）が主要な役割を果たしているが、構造シ ステムが単純で性能が安定していることの確認が比較的容易である、 いわゆるパッシブダンパが主に利用されてきた。これらのパッシブ ダンパによる応答低减効果は変位の低减効果と加速度の低減効果と に大別され、両低减効果が互いに背反する場合も多い。そこで、パ ッシブダンパの弱点を補うスマートパッシブダンパの工夫も種々提 案されて来ているが、理想的には、ダンパの特性を構造の灾答状龍 に応じて時々刻々に変動させることでパッシブ制御では実現が困難 である制御効果を生むことの策定も開始されている。このような制 御目的に使用寸るダンパをセミアクティブダンパと呼んでいる。セ ミアクティブダンパとしては可変式オイルダンパ、電気粘性流体ダ ンパ (ERダンパ)、磁気粘性流体ダンパ (MRダンパ) などが既に存 在寸るが、その中で、MRダンパは比較的低コストで制御力を連続的 に変動できることを利点として将来技術としての期待が大きい。 MRダンパを利用した構造物のセミアクティブ制御に関する研究 として、米国ではSpencerらによる研究が広く知られ1)、日本でも同 研究を踏まえて1998〜2002年の間日米共同研究が実施されている。 後者においては、制御アルゴリズムやダンパの力学性能の長期安定 性が必ずしも検証され尽くして居ないことを踏まえて極少量のキャ
パシティに止められたものの、2棟の実建築物にMRダンパを設置す るといら成果に結びつけられている2)。その後もダンパの長期安定性 （主に磁性鉄粉の沈殿対策）が大きくは向上していないために、同 ダンパが広汎に利用されるには今少しの時間を要するであろうが、 同ダンパを有効に活用するための制御アルゴリズムに関するさらな る検討を進めることには十分な意義が有るものと考えている。何れ にしても、セミアクティブ制御則の有効性を実験的に比較検証する ためには、数多くの振動台加振実験を行うことが必要であるが、前 記の日米共同研究におけるものに匹敵するような大型モデルを使用 する実験を実施する機会は得がたい実情である。そこで、本研究で は、新たに小型MRダンパを開発し、小型免震フレームと組み合わせ て多数の振動台実験を行うこととした。

本研究の目的はMRダンパを設置した免震構造物において、免震層 の変位と上部構造屋根階の絶対加速度の両応答を、他のパッシブ制 御による両応答よりも同時に下回ることを可能と寸るセミアクティ ブ制御則を策定する事である。はじめに、小型免震用MRダンパの構 造概要・単体性能・カ学モデルを記す。次いで、3層小型鉄骨フレー ムの下部を固定した場合、および免震層を付加した場合それぞれの 固有振動特性について記す。次に、応答予測制御、ファジィ制御、 最適レギュレータ制御、スカイフック制御、速度比例减衰制御等の 各種セミアクティブ制御手法の概要と実際の制御実験結果を記す。
* 早稲由大学理工学研究科 大学院生·工修

** 早稲田大学理工学研究科 大学院生

*** 早稲田大学理工学術院建築学科 教授. 工博
Graduate Student, Dept. of Architecture, Waseda University, M. Eng.

Graduate Student, Dept. of Architecture, Waseda University

Prof., Dept. of Architecture, Waseda University, Dr. Eng. 


\section{2. 小型 MR ダンパの概要}

\section{1 ダンパの構造 ${ }^{3)}$}

両ロッド式の $100 \mathrm{~N}$ 級 MR ダンパの構造を図 1 に示す。内径 $30 \mathrm{~mm}$ のシリンダ内でピストンが移動する時に、内蔵される MR 流体は内 径 $18 \mathrm{~mm}$ のバイパス流路を経由して移動する構造となっている。表 1 に諸元の一覧を示す。バイパス部 ${ }^{4)}$ には $7 \mathrm{~mm}$ の鉄芯を入れ（オリ フィス隙間 $5.5 \mathrm{~mm}$ )、電磁石は 2 個のコイルを直列に配置し、電流の 大小に応じて磁界が変化して MR 流体のせん断降伏応力も変化する。 温度と圧力による流体の体積変化の影響を除くために、アキューム レータが設置され、圧力はハンドポンプを用いて $0.2 \mathrm{Mpa}$ 程度に調 整・維持している。

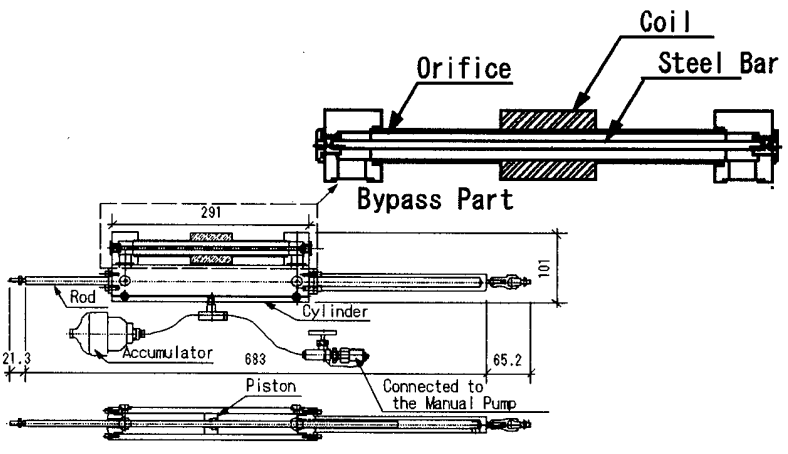

図 $1100 \mathrm{~N}$ 級 MR ダンパの構造図（単位:mm）

表 1 小型 MR ダンパの諸元

\begin{tabular}{|c|c|c|}
\hline \multicolumn{2}{|c|}{ 項 目 } & 仕様 \\
\hline \multicolumn{2}{|c|}{ Maximum Force } & $100 \mathrm{~N}$ \\
\hline \multicolumn{2}{|c|}{ Maximum velocity } & $30 \mathrm{~cm} / \mathrm{sec}$ \\
\hline \multicolumn{2}{|c|}{ Stroke } & $24 \mathrm{~cm}( \pm 12 \mathrm{~cm})$ \\
\hline \multicolumn{2}{|c|}{ Diameter of Cylinder Bore } & $30 \mathrm{~mm}$ \\
\hline \multicolumn{2}{|c|}{ Diameter of piston rod } & $10 \mathrm{~mm}$ \\
\hline \multicolumn{2}{|c|}{ Orifice(Steel bar) } & $5.5 \mathrm{~mm}(\varphi 7 \mathrm{~mm})$ \\
\hline \multirow{3}{*}{ Electromagnet } & Coil Cycles & $600 \mathrm{~T} \times 1$ \\
\hline & Resistance & $10.3 \Omega \times 1$ \\
\hline & Max Voltage & DC6 $\times 2$ \\
\hline \multicolumn{2}{|c|}{ MR fluid } & \#230(Bando Chemistry) \\
\hline \multicolumn{2}{|c|}{ Weight } & $45 \mathrm{~N}$ \\
\hline
\end{tabular}

\section{2 ダンパの動力学特性}

$\mathrm{MR}$ ダンパの力学特性を特定するため、コイルに $0,0.2,0.4,0.6,0.8$ $1,1.5,2,2.5,3 \mathrm{~A}$ の一定電流を印加し, 正弦波繰り返し加振赛験を行 った。図 2 に示すように、ダンパ荷重は、印加電流とピストン速度(振 動数)が増加するとともに上がり、ダンパ荷重とピストン変位の関係 は常に安定した履歴を描いている。MR ダンパは電流無印加の場合 にはオイルダンパの力学特性に良く似て荷重変形関俰が概ね棈円状 の履歴を描くが、ピストンとシリンダ間およびピストンロッドシー ル部分におかいて若干の摩擦力が生じることの影響が変形のピーク (速度=0)点で認められる。なお、本稿では、図 1 においてピストン の右方向への移動時の荷重を圧縮(正)と定義している。

上記単体加振実験により得られる最大荷重と最大ピストン速度の 関係をプロットしたものが図 3 であり、同図中の実線は電流值每に 実験結果を最小自乗法により直線で近似したものである。電流值を 0 3A と変える事によるダンパの減衰力の可変幅は、ピストン速度が 遅い場合に約 0 50 N、ピストン速度が早い場合には、10 100N とな
ることよりセミアクティブ制御に十分適用できると判断した。

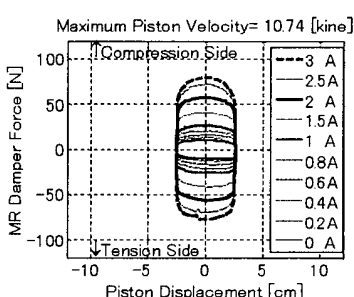

(a) 振動数 $0.5 \mathrm{~Hz}$, 振幅 $25 \mathrm{~mm}$

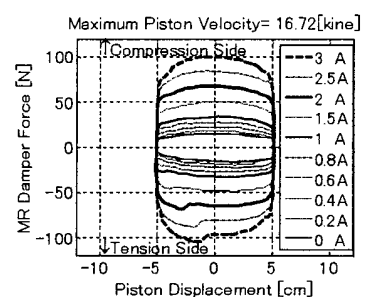

(b) 振動数 $0.5 \mathrm{~Hz}$ ，振幅 $50 \mathrm{~mm}$
図 2 正弦波加振に対するダンパの履歴特性

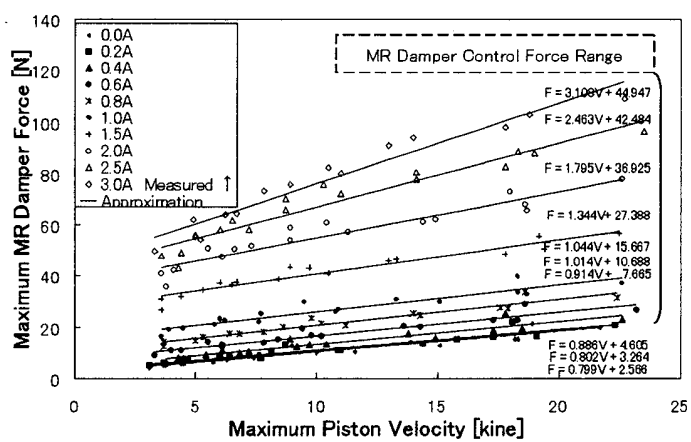

图 3 MRダンパの最大荷重-最大ピストン速度関係

\section{3 ダンパのカ学モデル}

図 3 に挿入されている直線は電流により勾配が異なり、また速度= 0 の点での摩擦抵抗力も電流值に比例はしていない。そこで、ダッ シュポット要素および摩擦要素の何れも電流変化に対して非線形で あるとし、それらを並列に組み合わせるビンガムモデルを用い、ダ ンパの荷重を式(1)で近似することとする。図 3 をもとにして、可変 粘性係数と可変滑り荷重ともに印加電流の 2 次関数に回帰して図 4(a)、図 4(b)のように近似した。特に滑り荷重に関しては、やや複雑 にはなるが精度を上げるために $\mathrm{I}=0.8 \mathrm{~A}$ を境にして係数を変えてあ る。

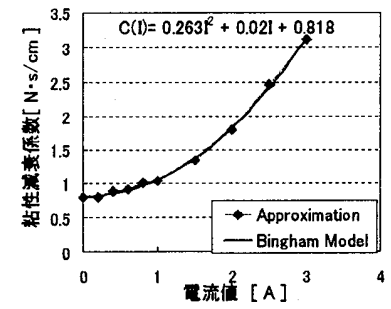

(a)粘性係数の電流依存性

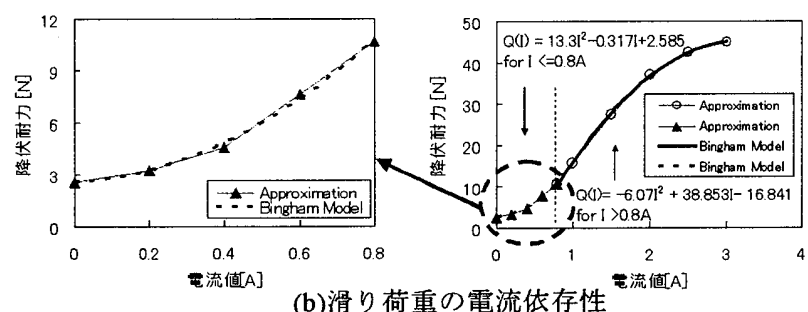

図 4 ビンガムモデルによる MR ダンパ荷重の同定

$$
F_{M R}=V^{*} C(I)+Q(I)
$$

ここに、

$F_{M R}: \mathrm{MR}$ ダンパの荷重、 $C:$ 粘性係数 $[\mathrm{N} \cdot \mathrm{s} / \mathrm{cm}]$ 、

$I:$ 印加電流 $[\mathrm{A}] 、 Q:$ 降伏耐力 $[\mathrm{N}] 、 V:$ ピストン速度[kine] 
3. 小型 3 層免罟フレームの概要

\section{1 上部 3 層鉄骨フレーム}

写真 1 の 3 層鉄骨フレームの各階質量と各階剛性を表 2 に示す。 試験体は SS400 鋼材を使用した。試験体の固有振動特性を検証する ために、基礎を固定した上部 3 層フレームをホワイトノイズ(バンド 幅 0 20Hz、最大振幅 $0.5 \mathrm{~mm}$ 、継続時間 $170 \mathrm{sec}$ )により加振し、FDD 法 $^{5)}$ (Frequency Domain Decomposition Method) を用いて固有振動数 と減衰定数の評価を行った。 1 次モードの固有周期は約 0.26 秒 $(3.796 \mathrm{~Hz})$ 、减衰定数は約 $1.2 \%$ あった。本加振により得られた伝達 関数を図 5 に示す。

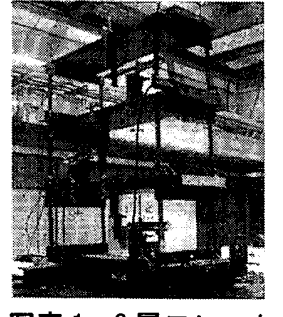

写真 13 層フレーム

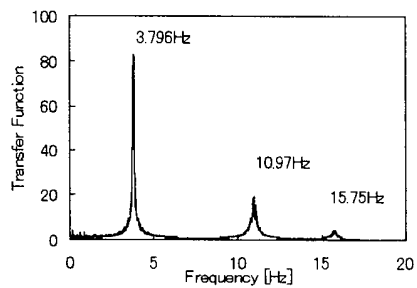

图 5 伝達関数（基礎固定）
表 2 試験体の頃量と剛性

\begin{tabular}{c||c|c}
\hline 階/層 & $\begin{array}{c}\text { 質量 } \\
{[\mathrm{N} / \mathrm{gal}]}\end{array}$ & $\begin{array}{c}\text { 剛性 } \\
{[\mathrm{N} / \mathrm{cm}]}\end{array}$ \\
\hline \hline 3 & 0.568 & 1710.0 \\
\hline 2 & 0.629 & 1660.0 \\
\hline 1 & 0.624 & 1660.0 \\
\hline 免茼 & 1.241 & 18.0 \\
\hline
\end{tabular}

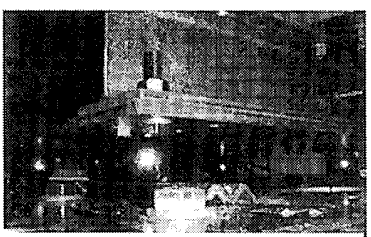

写其 2 V溝レールと

鎆球による支承

\section{2 免震装置}

摩擦力を低く抑えるために若干の試行錯誤の結果、免震装置は、 写真 2 に示すように、L- $20 \times 20 \times 3$ を利用した V 溝レール上を直径 $50.5 \mathrm{~mm}$ の鋼球が転がる単純な機構とした。その上に厚さ $9 \mathrm{~mm}$ 鋼板 の免震土台(1 階床)を設置した。

\section{3 免震層付き建物モデルの概要}

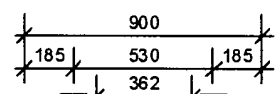

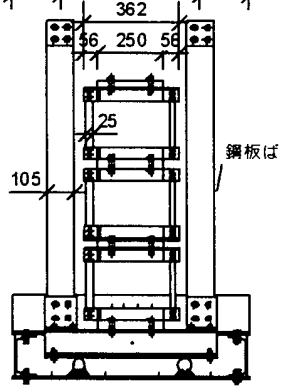

(a)正面図

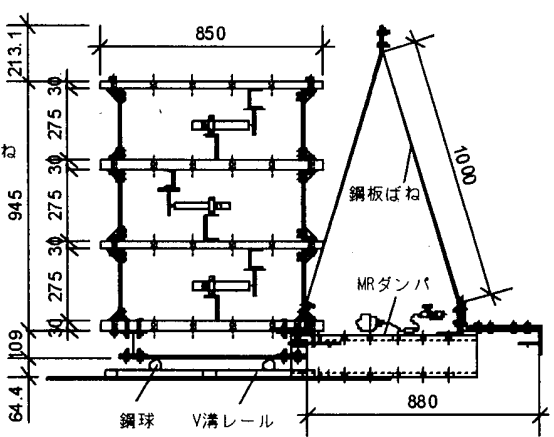

(b)側面図

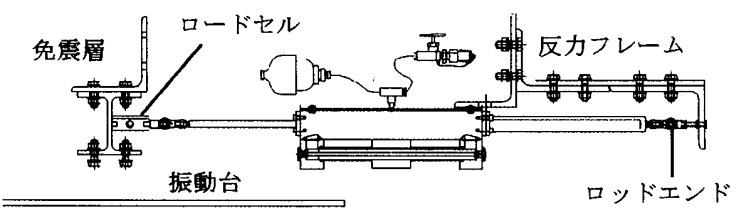

(c)ダンパ取り付け部の拡大図

图 63 層鉄骨免震フレームの構造図（単位:mm）
図 6(a)(b)に試験体構造図を示す、上部構造の総重量は 3,001Nで, 逆 $\mathrm{V}$ 型に設置した厚さ $4.5 \mathrm{~mm}$ の鋼板バネの水平剛性は $18.0 \mathrm{~N} / \mathrm{cm}$ で あり、鋼球が上部構造を載せてV 型清を転がる際のクーロン摩擦力 は $2.3 \mathrm{~N}$ となる。

このように構筑される免震フレームのホワイトノイズ波(バンド幅 $0 \sim 20 \mathrm{~Hz}$ 、最大振幅 $90 \mathrm{~mm}$ 、継続時間 $170 \mathrm{sec})$ に対する伝達関数は図 7 となる。1 次の固有周期は約 2.6 秒(1)のピーク)になり、1 次の堿衰 定数は約 3\%である。図中の(2) (4)は、上部構造の振動形に対応する ピークであり、その他のピークは水平ばねの振動に起因するもので ある事を確認してある。

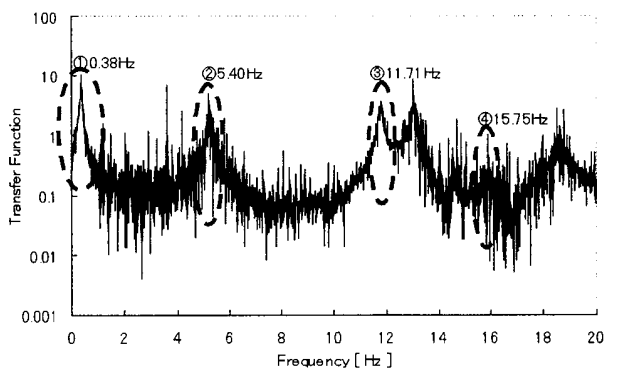

図 7 伝達関数 (免震建物)

4. セミアクティブ制御実験の概要

\section{1 実験の進め方}

本研究で適用するセミアクティブ制御のためのアルゴリズムの多 くは、事前にパラメータを適切に設定しておくことが必要である。 本章の4.2節で地震応答解析用4質点系モデルに対して制御力の項を 含む振動方程式の一般的な定式化を示す。解析では4質点系モデルを 用いて、免震層の変位と最上階の絶対加速度を同時に抑えることを 目標にして最適な制御パラメータを策定した。4.3節には適用する各 種制御アルゴリズムにおける制御力の設定方法の概要を記す。

\section{2 地震底答解析モデル}

図 8 には、図 6 の免震試験体のセミアクティブ制御解析モデルを 示す。上部構造を 4 質点系 $\left(\mathrm{m}_{0} \sim \mathrm{m}_{3}\right)$ 、免震層鋼板バネを線形バネ $\left(\mathrm{k}_{0}\right)$ とダッシュポット $\left(\mathrm{C}_{0}\right)$ 、鋼球と V 清レールの接触面を摩擦要素 $\left(F_{r}\right)$ で代表する。これらの変数を用いて運動方程は式(2)となる。

$$
\mathbf{M} \ddot{\mathbf{x}}+\mathbf{C}_{\mathbf{S}} \dot{\mathbf{x}}+\mathbf{r} F_{r}+\mathbf{r} F_{M R}+\mathbf{K x}=-\mathbf{M} \mathbf{1} \ddot{x}_{g}
$$

ここに、 $\mathbf{M}$ は質量マトリクス、 $\mathbf{K}$ は䍏性マトリクス、 $\mathbf{C}_{\mathbf{s}}$ は減衰係数

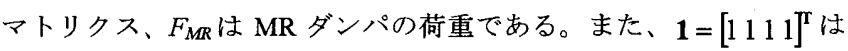
単位ベクトル、 $\mathrm{x}=\left[x_{0} \cdots x_{3}\right]^{\mathrm{T}}$ は各階の基整に対する相対変位、 $x_{g}$ は基

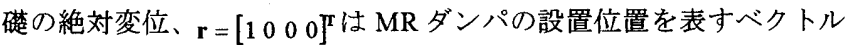
である。

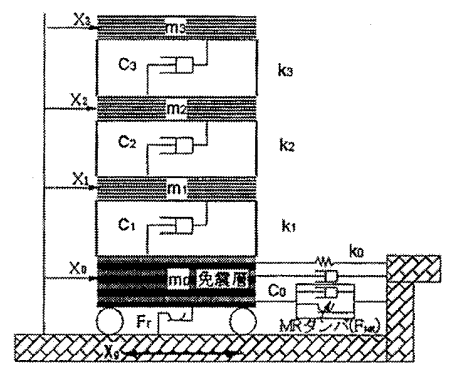

図 8 地震応答解析用モデル 
式(2)を相対加速度ベクトルで表すと、下記の通りになる。

$$
\ddot{\mathbf{x}}=\mathbf{M}^{-\mathbf{1}} \mathbf{K x}-\mathbf{M}^{-1} \mathbf{C}_{\mathbf{S}} \dot{\mathbf{x}}-\mathbf{1} \ddot{x}_{\boldsymbol{g}}-\mathbf{M}^{-1} \mathbf{r} F_{r}-\mathbf{M}^{-1} \mathbf{r} F_{M R}
$$

これより、式(4)の状態方程式と式(5)の出力方程式が得られる。

$$
\text { 状態方程式 : } \dot{\mathbf{z}}=\mathbf{A z}+\mathbf{B f}
$$$$
\text { 出力方程式 : } \mathbf{y}=\mathbf{C z}+\mathrm{Df}
$$

ここに、A，B，C，Dマトリクスは下記の通りである。

$$
\begin{array}{ll}
\text { システムマトリクス } & A=\left[\begin{array}{cc}
\mathbf{0}_{4 \times 4} & \mathbf{I}_{4 \times 4} \\
-\mathbf{M}^{-1} \mathbf{K} & -\mathbf{M}^{-1} \mathbf{C}_{\mathbf{S}}
\end{array}\right] \\
\text { 入カマトリクス } & \mathbf{B}=\left[\begin{array}{ccc}
\mathbf{0}_{4 \times 1} & \mathbf{0}_{4 \times 1} & \mathbf{0}_{4 \times 1} \\
-1 & -\mathbf{M}^{-1} \mathbf{r} & -\mathbf{M}^{-1} \mathbf{r}
\end{array}\right] \\
\text { 出カマトリクス } & \mathbf{C}=\left[\begin{array}{cc}
\mathbf{I}_{4 \times 4} & \mathbf{0}_{4 \times 4} \\
\mathbf{0}_{4 \times 4} & \mathbf{I}_{4 \times 4} \\
-\mathbf{M}^{-1} \mathbf{K} & -\mathbf{M}^{-1} \mathbf{C}_{\mathrm{s}}
\end{array}\right] \\
\text { 直達マトリクス } & \mathbf{D}=\left[\begin{array}{ccc}
\mathbf{0}_{4 \times 1} & \mathbf{0}_{4 \times 1} & \mathbf{0}_{4 \times 1} \\
\mathbf{0}_{4 \times 1} & \mathbf{0}_{4 \times 1} & \mathbf{0}_{4 \times 1} \\
-1 & -\mathbf{M}^{-1} \mathbf{r} & -\mathbf{M}^{-1} \mathbf{r}
\end{array}\right]
\end{array}
$$$$
\text { 入力ベクトル } \mathbf{f}=\left[\begin{array}{lll}
\ddot{x}_{g} & F_{r} & F_{M R}
\end{array}\right]
$$

\section{3 制御アルゴリズム}

一般的な免震建物が地震力を受ける時の免震層の応答は、上部構 造を剛体と見なした場合の応答と大差ない。実際に本構造モデルで も上部を㴊体とした1質点モデルの周期と、図7に見られる多質点系 の固有周期は何れも約2.6秒であり両モデルの免震基䃈の動きはほ ぼ同等と考えることが出来る。従って、制御実験を行う時は、MR ダンパの制御力は免震モデルを 1 質点系(SDOF)として算出するこ ととした。非制御の場合に免震層の最大変形が $12 \mathrm{~cm}$ に収まるように 基準化した入力に対してセミアクティブ制御効果が最も高くなるよ うに制御パラメータの值を決めた。ここで、ある地震動に対する制 御パラメータの最適值は、各セミアクティブ制御時と非制御(電流無 印加)時の、免震首の最大相対変位の比と、最上階の最大絶対加速度 の比の2乗和平方根が最小となる值(最適判断値)と定義する。さらに、 各地震動について決定したその值の平均値を最小とする時のパラメ ータを最適パラメータとする。以下に実験で用いた種々の制御則の 概要を記す。

\section{3. 1 MR ダンパのパッシブ使用(以下、 $\mathrm{CC}$ 制御)}

本制御では、MR ダンパに定電流を $0 \mathrm{~A}$ から $3 \mathrm{~A}$ まで $0.5 \mathrm{~A}$ 刻みで 作用させて、パッシブダンパとして用いる。

\section{3.2 速度比例制御 (以下、CV 制御)}

MRダンパを用いて速度比例型オイルダンパの力学特性を模擬す る制御である。ダンパの粘性减衰係数は建物モデルの上部構造を剛 体と見なしたSDOFの剛性比例减衰系としてその減衰定数が $10 \%$, $20 \%, 30 \%, 40 \%$ に対応寸る棈円型の履歴を描くように時々刻々変化 させるように決める。本制御ではダンパの特性が変動するので綮密 にはパッシブ制御では無いが、パッシブオイルダンパの特性を模擬 することから、パッシブ制御の範疇に加えることにする。

\subsection{3 ファジィ制御(以下、FC 制御)}

筆者らがファジィ 2 次元推論による MR ダンパのセミアクティブ
制御の有効性を解析的に確認した結果を応用するの。表 3 に示すよ うに、2 次元の制御規則は、前件部を免震層相対変位と同相対速度 として、後件部の制御力を決めることとした。また、态答変位や忘 答速度、制御力の規則は、ゼロを中心にした正負 3 段階のファジィ 集合を用い、NB(負で、大きい值)、NM(負で、中ぐらいの值)、NS(負 で、小さい值)、ZR(ゼロ)、PS(正で、小さい值)、PM(正で、中ぐら いの值)、 $\mathrm{PB}$ (正で、大きい值)と定義している。免震層の応答変位が 大きい時には、応答変位フィードバック制御を行い、応答変位が小 さい時には，応答速度フィードバック制御を行って、応答速度がゼ 口の時は制御力をゼロにすることとする。図 9 に态答情報（前件部） に対するフィードバック制御力（後件部）曲面を示す。
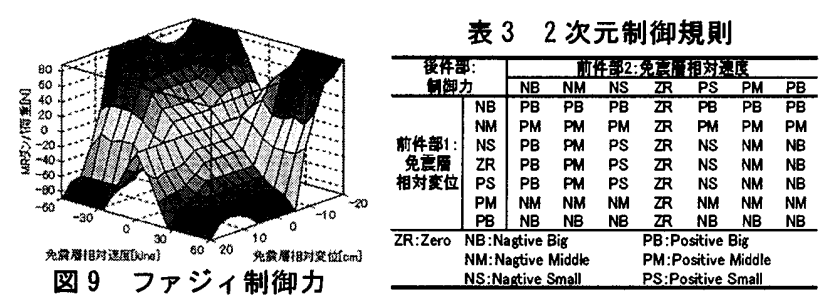

\subsection{4 スカイフック制御（以下、SH 制御）}

スカイフック制御 》では、文献 8 の手法により式(6)に示すような 印加電流と免震層相対速度を制御条件とし、後に 7 項に例示する予 備解析により最適な境界值を決める。ダンパへの印加電流は式(6) と なり、 $A_{1}$ と $A_{2}$ は印加電流[A]の境界値、 $V_{1}$ と $V_{2}$ は免震層相対速度 [kine]の境界值である。なお、式(7)に示寸ように、免震層の相対速度 と絶対速度の符号が逆の場合には、電流を印加しない。

$$
\begin{aligned}
& I_{S H}=\left\{\begin{array}{crr}
\mathrm{A}_{2} & \text { for } & \begin{array}{r}
\left|\dot{x}_{o}\right|>\mathrm{V}_{2} \\
\mathrm{~A}_{1}
\end{array} \\
0 & \left|\dot{x}_{o}\right| \leq \mathrm{V}_{2}
\end{array}\right. \\
& I= \begin{cases}I_{S H} & \left(\dot{x}_{o}\right)\left(\dot{x}_{g}+\dot{x}_{o}\right) \geq 0 \\
0 & \left(\dot{x}_{o}\right)\left(\dot{x}_{g}+\dot{x}_{o}\right)<0\end{cases}
\end{aligned}
$$

\subsection{5 最適レギュレータ制御 (以下、LQR 制御)}

最適レギュレータ制御 ${ }^{9,10}$ (Linear Quadratic Regulator)の目標は応 答と制御力の大きさをバランス良くすることであり、式(8)の評価関 数(Criterion function)を最小化する事を基本とする。

$$
J=\int_{0}^{\infty}\left[\mathbf{x}^{\mathrm{T}} \mathbf{Q} \mathbf{x}+R u^{\hat{2}}\right] d t
$$

ここに、 $\mathbf{x}, u$ は建物の㐫答と制御力であり、 $\mathbf{Q}$ とR $R$ 重み関数であ る。ダンパの制御力は式(9)になる。

$$
F_{M R}=-R^{-1} \mathbf{b}^{\mathbf{T}} \mathbf{P}=-\mathbf{K x}
$$

ここで、Pは $2 \times 2$ のマトリクスであり、式(10)のリッカティ方程式 (Riccati Equation)を満たす正定唯一解であり、bはSDOF としての入 カマトリクスである。 $\mathbf{K}(1 \times 2)$ を最適フィードバックゲインと乎ぶ。

$$
\mathbf{P A}+\mathbf{A}^{\mathbf{T}} \mathbf{P}-\mathbf{P b} R^{-1} \mathbf{b}^{\mathbf{T}} \mathbf{P}+\mathbf{Q}=\mathbf{0}
$$

一連の試行錯誤的予備解析により、変位を抑えつつ加速度を抑制 するのに最も適したパラメータは、4.3節に記した方法で探索した結 果、重み関数は $\mathbf{Q}=\operatorname{diag}\left(\left[\begin{array}{ll}100 & 100\end{array}\right]\right), \mathrm{R}=5$ を用い、フィードバックゲ インは $\mathrm{K}=\operatorname{diag}([-1.5078-4.7474])$ とした。 


\subsection{6 応答予測制御(以下、FF 制御)}

後に5章に制御結果を記す通り、通常の粘性減衰パッシブダンパも、 减衰係数の決め方によっては十分に効果的である。そこで、粘性减 衰をさらに勃果的に利用するために、免震層の変形がゼロとなる時 の速度に応じて減衰係数(减衰定数)を可変とする制御則として、1/4 サイクル前の変位のピーク時に、次に原点を通過する際の速度を予 め予測するようにした。

図10に例を示す ように、1 質点系に 変換した上記の免 震構造モデルの地 震応答解析により 得られる図11の変 形の時刻歴を基に して、応答変位が原 点を横切る時の運 動エネルギーとそ

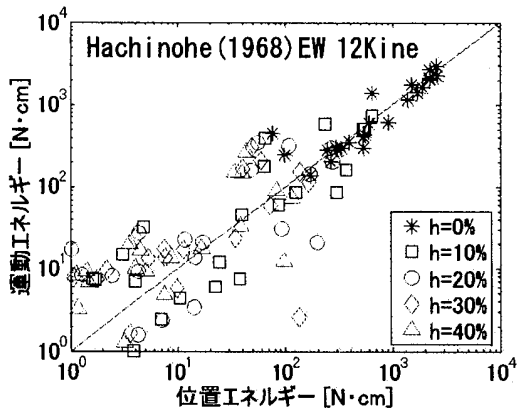

図 10 SDOFによる振動エネルギーの関係
れに対応する約 $1 / 4$ サイクル前の変位のピークにおける歪エネルギ 一の関倸をプロットすると図10となる。これより、応答レベルの高 い領域では、減衰の大小によらず、位置エネルギーと運動エネルギ 一は、互いに1对 1 の関倸として近似できることがわかった。この関 係を利用して応答予測を交えた制御則を下記の通りに構筑した。

免震層の剛性を $\mathrm{k}_{0}$ 、免震建物全体の質量を $\mathrm{m}$ と寸る。免震層の态 答速度を予測する場合には、図 11 に示すように時々刻々に免震層の 応答をモニターし、各免震層のピーク変位（例えば、速度がゼロで ある:(2)）毎に位置エネルギーおよび運動エネルギーの関係を用い、 次に原点を通過する時のピーク速度 $V_{i}$ (5)）を予測することが出来 る。これを利用して、

本制御アルゴリズムでは制御力を、

$$
F_{M R}=2 h_{i} \dot{x}_{o}(t) \sqrt{\mathrm{k}_{0} \mathrm{~m}}
$$

とする。ここでは、半サイクルごとに変化する減衰定数は $20 \%$ 40\% の間で変化させることとして、下式とした。

$$
h_{i}=0.2+\alpha\left|V_{i}\right| \leq 0.4
$$

ここに、 $\alpha=0.01(\mathrm{~s} / \mathrm{cm})$ である。

\subsection{7 最適パラメータの策定例}

4.3節の末尾に記した方法により、本研究ではセミアクティブ制御 のための最適パラメータを事前解析により探索している。SH制御の
場合の探索例を図12に示す。表4は式(6)により設定した免震層相対 速度の境界值と、免震層相対速度の境界值に対する種々の印加電流 であり、それらを組み併せて得られた最適性評価值を最右列に記し てある。図中の※印が最適なSH制御パラメータに対応している。各 セミアクティブ制御について、このように定めたパラメータ值を用 いて行った実験結果を5章では相互に比較している。なお、事前解析 で使用する外乱は振動台上で事前に記録した波形である。
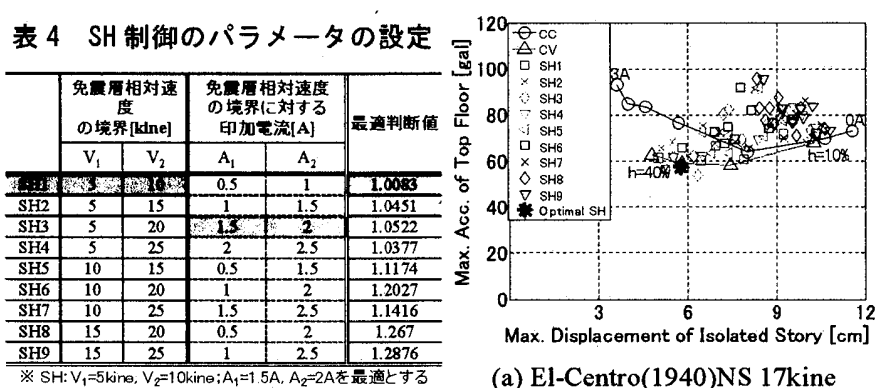

(a) El-Centro(1940)NS 17kine

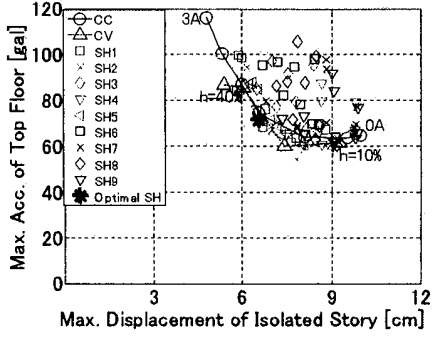

(b) Kobe(1995)NS 26kine

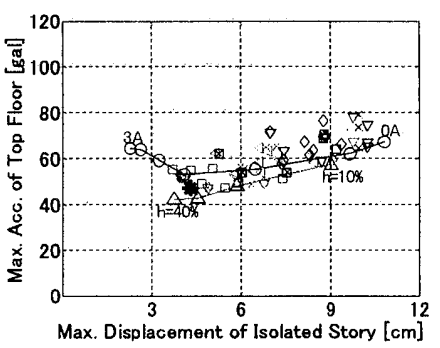

(c) Hachinohe(1968)EW 12kine
図 12 事前解析による最適な SH 制御パラメータの策定

\section{4 振動台実験システム}

\section{4.1 振動台}

本実験では早稲田大学喜久井町キャンパス第 2 研究棟に設置され た $1,000 \mathrm{kN}$ 動的アクチュエータの先端に直動ベアリングで支持され た梁を取り付け、その上にさらに $900 \times 1400 \times 9 \mathrm{~mm}$ の鋼板を取り付 けて振動台とした。後に図 $15 、 16$ で見る通り、必ずしも目標とする 原波形を正確には模擬できないが、実験の繰り返しに対する再現性 の高いことは確認してある。

\section{4.2 計測システム}

各計測装置の設置状況を図 13 に示す。試験体の各床面に加速度計 (ARF-10A および ARF-20A)、層閒に接触式変位計(DLT-20AS)、加力 梁のヘッドに接触型変位計(SDP-200D)、免震層にロードセル (TKA-50A)を設置した。免震層の変位測定には接触式変位計

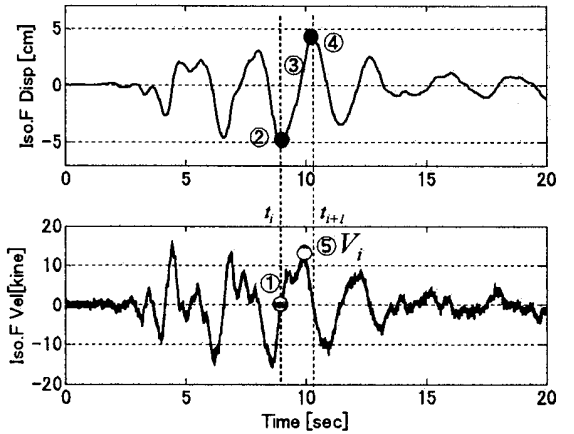

図 11 振動エネルギーによる応答速度の予測

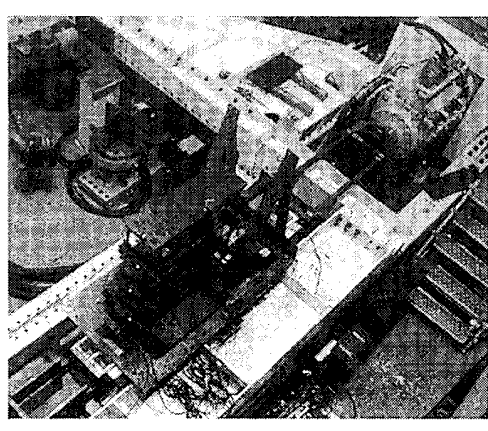

写真 3 振動台とアクチュエータ

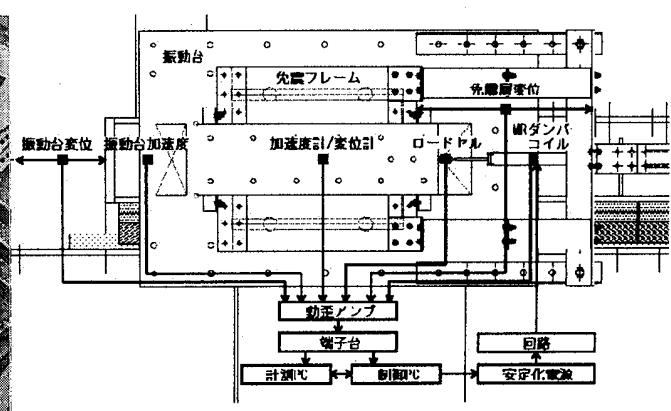

图 13 計測と制御装置の配置 
(DLT-150AS)を用いた。また、MR ダンパへの印加電流を計測するた め、1 のの抵抗をダンパのコイルに直列結合してある。

\section{4.3 制御システム}

制御 PCには MATLAB/Simulink ${ }^{11)}$ 及び高速デジタル信号処理ボー ド(DSP- 6367)をインストールし、200Hz のサンプリング時間でセミ アクティブ制御実験を行った。DSP ボードは分解能 14bit の AD コ ンバータと 16bitの DA コンバータをそれぞれ4チャンネル備えてい る。図 14 に示すようなブロック線図のセミアクティブ制御則を C コードにより生成し、リアルタイムで MR ダンパの目標抵抗力に対 応する電流值を制御する。すなわち、 $\mathrm{AD}$ コンバータからの変位信 号を微分した速度信号と、セミアクティブ制御則により算定した制 御力から、式(1)のビンガムモデルにより目標荷重に相当する電流值 を算定する。電流は DA コンバータを経由し、安定化電源から MR ダンパのコイルに印加される。なお、電磁石の定格電圧を超えない よう、印加電流の最大値は $3 \mathrm{~A}$ に設定した。

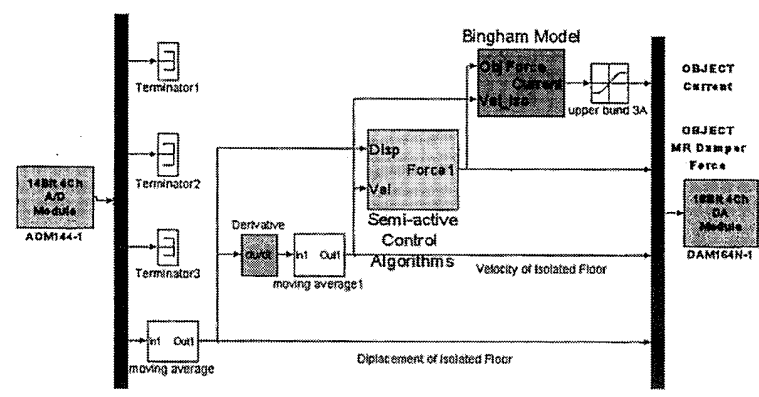

図 14 Simulink によるセミアクティブ制御

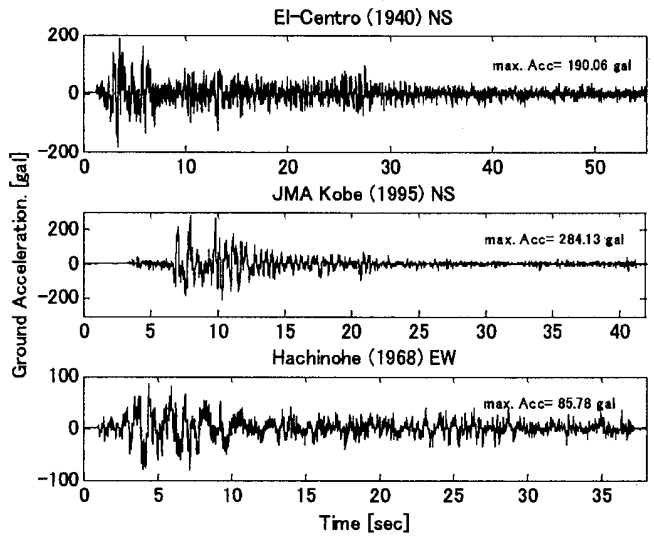

図 15 振動台水平加速度の時刻歴

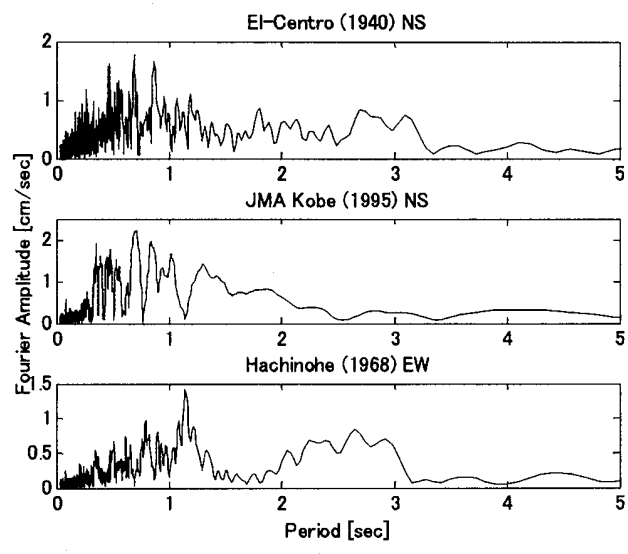

図 16 振動台水平加速度のフーリエスペクトル

\subsection{4 入力外乱}

El-Centro(1940)NS、JMA Kobe(1995)NS、Hachinohe(1968)EW を用 い、事前の予備解析により $\mathrm{CC}$ 制御 $(0 \mathrm{~A})$ の時に免震層の変位が $\mathrm{MR}$ ダンパのピストンの制限変位である $12 \mathrm{~cm}$ を超えないよう、それぞ れの地震波につき、その最大速度を 17kine、26kine、12kineに規準 化した。振動台上で記録した加速度波形の例を図 15 に示す。これら の振動台水平加速度をフーリエ変換し、得られたフーリエスペクト ルを図 16 に示す。

\section{5. 実験結果および考察}

\section{1 各階最大応答分布の比較}

使用した入力地震動ごとに、基礎(Floor：0)に対する各階床の最大 変位(Floor：1４)の分布を図17に示す。図中の記号は4.3節に記した 制御アルゴリズムの違いに対応している。セミアクティブ制御の結 果は、前述の方法による最適化パラメータを用いた場合に対応して いる。図18は各階の最大絶対加速度である。これらの図に基く考察 の要約は下記の通りになる。

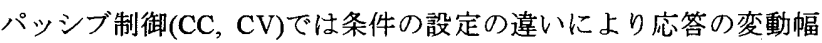
が広いが、セミアクティブ制御では何れの地震波、何れのセミアク ティブ制御則(FC, FF, SH, LQR)の組み合わせに関わらず応答の変動 幅は小さく、良好な制御効果が得られる。また、制御において免震 床の応答情報のみに基いて制御している事の誤差は十分に小さいも のと考えられる。

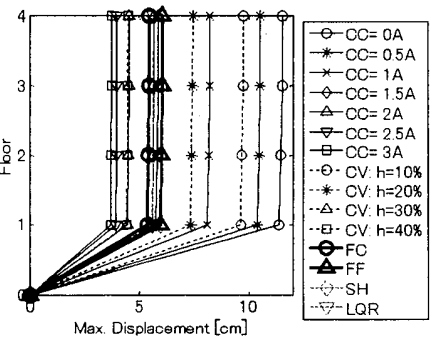

(a)El-Centro(1940)NS 17kine

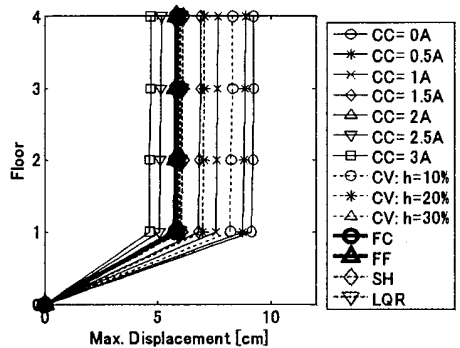

(b)Kobe(1995)NS 26kine

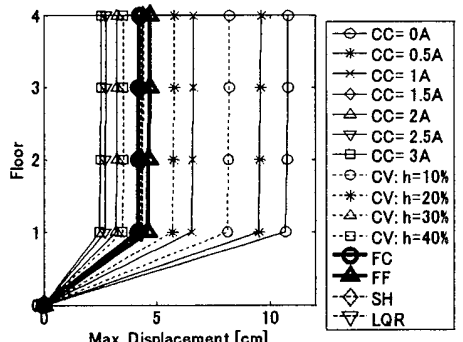

(c)Hachinohe(1968)EW 12kine

図 17 各階の最大相対変位

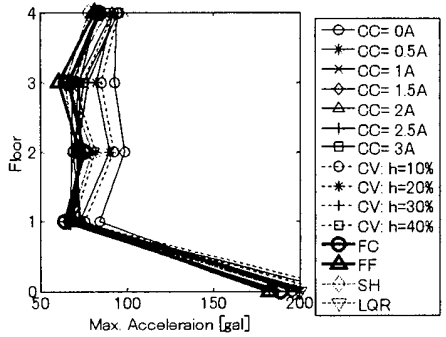

(a)El-Centro(1940)NS 17kine

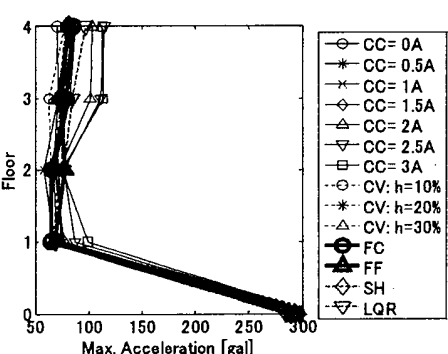

(b)Kobe(1995)NS 26kine

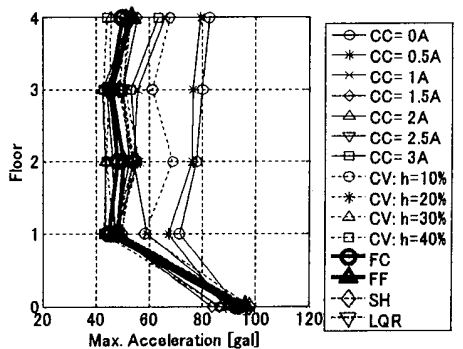

(c)Hachinohe(1968)EW 12kine

図 18 各階の最大絶対加速度 


\section{2 パッシブ制御時の荷重変形関係}

\subsubsection{CC 制御の場合}

図19は、El-Centro(1940)NS17kine 波を用いて MR ダンパの定電流 制御を行った時の荷重とピストン変位の関係である。安定した履歴 が得られ、印加電流の增加によってダンパ荷重が增加するとともに 変位が低减している。ただし、ダンパの荷重が過度に増加すると上 部構造の加速度が増加する要因となり易い事を図 17、18 中の CC 制 御における印加電流值の違いに対応して確認できる。

\subsubsection{CV 制御の場合}

図20(a)は、El-Centro(1940)NS17kine波に対するMRダンパのCV制 御の荷重とピストン変位の関係である。想定する减衰定数が増加す るにつれ、ダンパ荷重が増加し、変位が低減寸る一方で加速度応答 が増加するのはCC制御と同じ傾向であるが、CC制御よりも加速度 応答を增加させる好ましくない影響は小さい。図20(b)は、本CV制御 におけるダンパの速度と抵抗力の関係例を示す。完全な粘性减衰で あればこの関倸は直線になるはずである。MRダンパは本来非線形で あるので必ずしも直線にならないが、実験において、この程度には 粘性減衰を模擬できている事を確認できる。本制御において、変位 のピーク（速度がゼロ）で荷重がゼロにならないのは、ダンパの摩 擦の影響と考えられる。

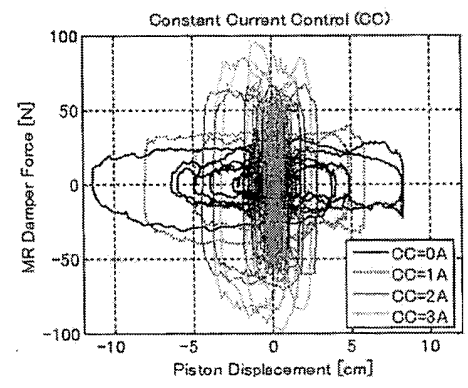

图 19 CC 制御の荷重·変形関保

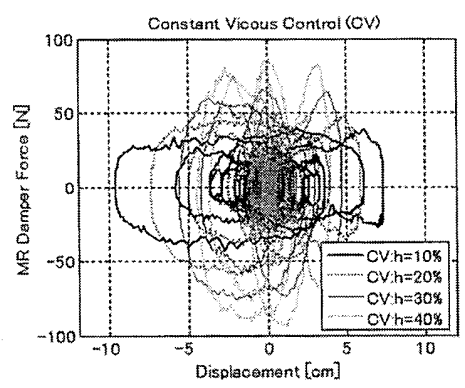

(a)待重-変形関保

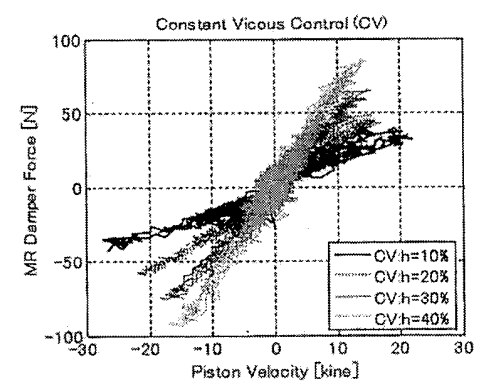

(b)荷重-速度関保
图 20 CV 制御の履歷

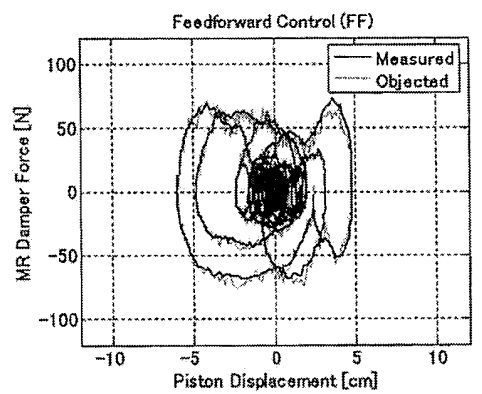

(a)FF 制御の㕍歷

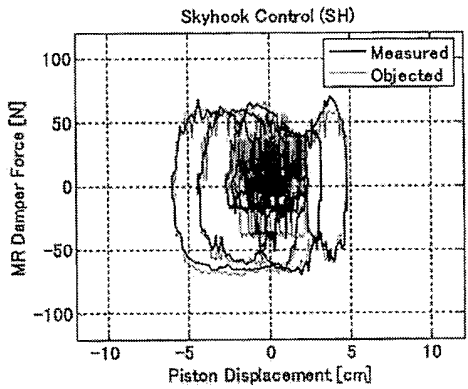

(b)スタイフック制御の履歴
図 21 目標履歴と実測履歴の比較

\section{3 セミアクティブ制御時の荷重変形関係}

El-Centro(1940)NS17kine波を用いたセミアクティブ制御により得 られた免震層の荷重変形関係の例を図21に示す。(a)図はFF制御、(b) 図はSH制御の場合である。太い実線はロードセルの実測荷重と実測 変位の履歷、細い実線は各制御則に基づいて算定した目標荷重と実 測変位との履歴である。FF及びSHのセミアクティブ制御が制御則通 りに実現されて居ることを確認できる。

図22はHachinohe(1968)EW12kine波を用いて、FF制御を行った場合 の免震層が変形ゼロを通過する時点の予測速度（O印）と実測速度 の絶対值の時刻歴である。4.3.6項の図10に見られる程度の予測誤差 が伴うため、図22でも半サイクルごとに予測した速度は、全てのピ 一ク速度に対応しないが、予測した速度の傾向は概ね実測速度と同 等である。この予測した速度を用い、式(12)により決めた减衰定数 の時刻歴を図23に示す。さらに、この减衰定数と免震層相対速度を 用い、式(11)に与える制御力と印加電流の時刻歴を図24に示寸。こ れらの印加電流の変化は、免震層相対速度の変化と対応する。

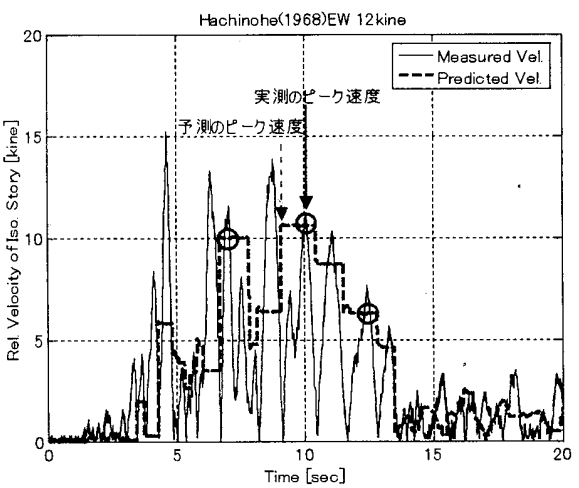

図 22 予測速度と実測速度の時刻歴（FF 制御）

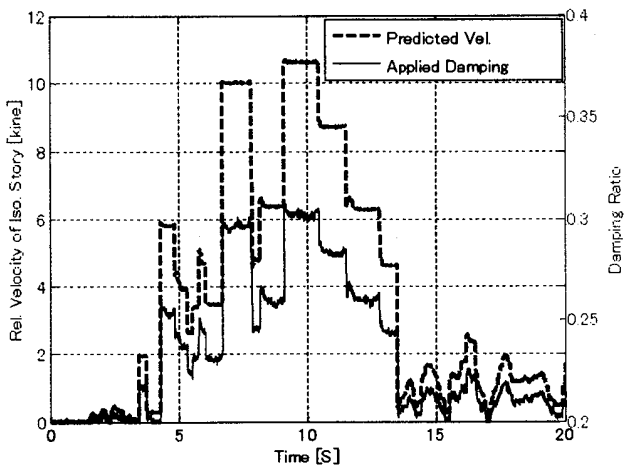

図 23 予測速度と実測隇衰定数の時刻歴（FF 制御）

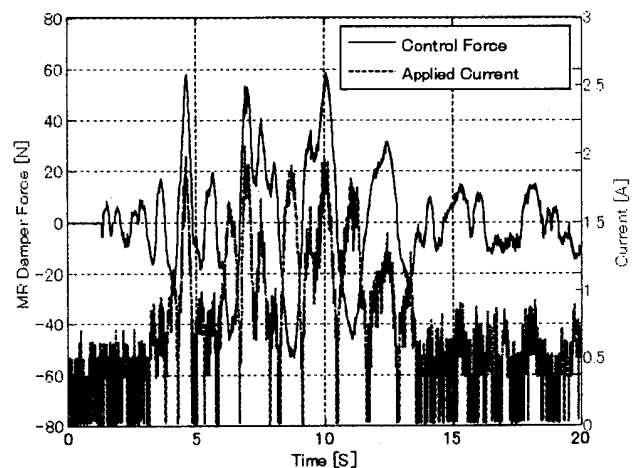

図 24 印加電流と荷重の時刻歴 (FF 制御) 

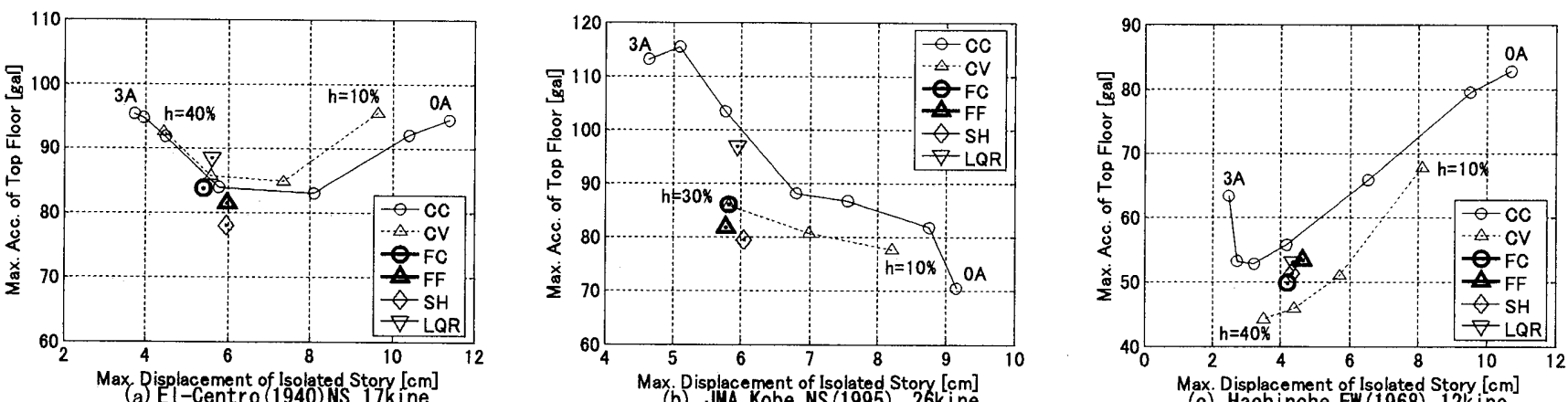

图 25 最上階最大加速度と免震層最大変位によるトレードオフ関係

\section{4 応答変位と応答加速度のトレードオフ関係}

セミアクティブ制御およびパッシブ制御の制振効果を比較するた め、図25に、各制御アルゴリズムを用いた振動台実験から得られた 最上階の最大絶対加速度と免震層の最大変位の関倸をプロットした 結果を示す。先に、制御アルゴリズムの最適化の目安としたのと同 様に、プロットが原点に近いほど、総合的に、より制御効果が高い と考えている。

\subsection{1 パッシブ制御の考察}

Kobe波の場合において、CC制御の印加電流とCV制御で設定する 减衰定数が高いほど応答変位は抑えられているが、最大応答加速度 はほぼ単調に増加している。これに対して、El-Centro波の場合には、 変位に関してはほぼ同じ傾向であるが、最大加速度は印加電流の增 加とともに一旦下がってから再び増加する。Hachinohe波の場合には、 CC制御ではEl-Centro波の場合と同様に加速度応答が極值を有する のに対して、CV制御では减衰定数の増加につれて、変位、加速度の 何れも単調に減少する。Hachinohe波におけるCV制御、また、Kobe 波における両制御実験結果で加速度応答に極值が見られていないが、 図12の事前解析ではいずれにおいても僅かに極值が認められている。 これは、実験パラメータの範囲の選択が影響したものと思われる。 このようにパッシブ制御におけるトレードオフ関係は地震動の特性 の影響を強く受ける。

\section{4 .2 セミアクティブ制御の考察}

Kobe 波と Hachinohe 波に対して、LQR 制御による応答制御効果は CC 制御より良好な結果が得られるが、El-Centro 波に対しては、LQR 制御の勃果が低い結果となった。El-Centro 波と Kobe 波に対する SH 制御の効果は良好な結果となったが、Hachinohe 波に対しては CV 制 御よりも効果が低い結果となった。

El-Centro 波と Kobe 波に対する FC 制御と FF 制御は、 CC 制御お よび CV 制御と比較すると、最大応答変位の制御効果は同等である ものの、最大応答加速度はよく抑制する結果となった。Hachinohe 波については、CC制御と比較して良い制御効果が得られるものの、 $\mathrm{CV}$ 制御よりは効果が低い結果となった。Kobe 波に対しては、FF 制 御の制御効果が FC 制御より若干良く、Hachinohe 波に対しては、FC 制御の結果が、FF 制御より若干良い。

総括的に言えば、セミアクティブ制御が常にパッシブ制御より良 い制振効果をもたらすとは言えないものの、パッシブ制御は堿衰機 構の違いやパラメータの設定值の違いによる制御効果への影響が大 きい。一方、応答予測制御（FF 制御）やファジィ制御は、定電流制 御より良い制御効果を得ることが出来、Hachinohe 波に対して速度 比例制御はより加速度を抑えることが確認されるなど、地震動の違
いによらず、絶対值としては安定した応答抑制に有効な手法と考え られる。

6. まとめ

本稿では, 小型MRダンパを用いた免震フレームモデルの振動台実 験によりパッシブ制御とセミアクティブ制御の比較検討を行った。 実験結果により得られた知見を要約すると以下の通りとなる。

1)MRダンパの単体実験結果より、ビンガムモデルを用いてダンパ の荷重変形関係を模擬することの有効性を確認した。

2)小型免震フレームと小型MRダンパの組み合わせによる振動台 実験によっても、研究の目標である、多様なパッシブ制御とセミア クティブ制御の比較検討を達成する事が出来た。

3)パッシブ制御においても十分に応答は低減できるものの、最適 な制御のための条件設定が難しく、地震動特性の影響を強く受ける。

4)セミアクティブ制御が常にパッシブ制御を上回る結果とはなら なかったものの、応答予測を交えたセミアクティブ制御は比較的良 好かつ安定した制御効果を発揮すると考えられる。

5)セミアクティブ制御のための最適なパラメータを決めるための 事前解析結果と、実験結果との対応は概永良好であり、ダンパのモ デル化や、1 自由度系による近似制御に大きな問題の無いことを確 認できた。

謝辞

本研究は 2005 年度科学研究費基船 B -一般(代表者：曾田五月也 17360276)及び私立大学学術研究高度化推進事業(代表者曾田五月也) より助成を受けて行った。小型 MR ダンパの設計、製作には、(有) シズメテックの協力を賜りました。

\section{考文献}

1) Spencer Jr., B.F., Dyke, S.J., Sain, M.K. and Carlson, J.D. : Phenomenological Model of a Magneto- rheological Damper, J. Engrg. Mech., ASCE, Vol.123, pp. $230-238,1997$

2) 日米共同構造奏験研究「高知能建筑構造システム開登」芰術調整委員会, 独立行政法人建筑研究所, 国土交通省国土技術政策総合研究所, (財) 本建筑七多一: 米共同構造実駼研究「高知能建策構造システムの開 発」平成15年報告書, pp. V -1 V - $143,2003.3$

3) MR-2 ダンパ取り报い説明書,ジ゙メテック,2004.11

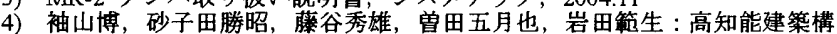
袖山博, 砂子田勝昭, 藤谷秀雄, 兽思五月也, 岩田籁生: 高知能建築構

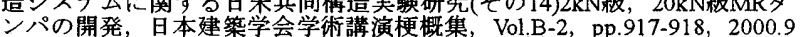

5) Brincker, R., Zhang, L. and Andersen, P.: Modal Identification from Ambient Responses using Frequency Domain Decomposition, Proc. of the 19th IMAC, pp. $625-630,2001.2$

6）沈里通，曾田五月也，内藤雄介，荻野和臣：MRダンパを設置した小型 3 首免震フレームのファジィ推論に基つくくミアアンィブ振動制御解析, 第12回地震工学シンポジウム論文集, pp.1034-1037, 2006.11

7) Karnopp, D. Crosby, M. J. and Harwood, R. A.: Vibration Control using Semiactive Force Generators, Journal of Engineering for Industry, Trans. ASME, p. $619-626,1974,5$

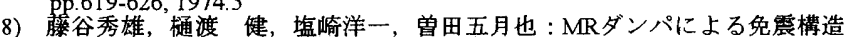
のスカイフック制御実験, 構造工学論文集, Vol.49B, pp.105-110,2003.3

Franklin, G.F., Powell, J.D. and Emami-Naeini, A.: Feedback control of

Dranklin, G.F., Powell, J.D. and Emami-Naeinl, A.:

10) Dynamic Systems, pp.492-645, Prentice Hall, 2002 最適レギュレータ理䄖を

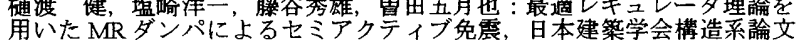
集, No.567, pp.47-54,2003.5

11) Dabney, J.B. and Harman, T. L.: Mastering Simulink, pp.49-218, Person Education, 2004 